\title{
PEMIKIRAN MUHAMMAD ABIED AL-JABIRI SEBAGAI PROYEK KEBANGKITAN ISLAM
}

\author{
Yuni Pangestutiani \\ cantiky304@gmail.com
}

Dosen Ilmu Tasawuf IAI Pangeran Diponegoro Nganjuk

\section{Abstrak}

Abied al-Jabiri adalah seorang jawara filsafat Arab yang tak tertandingi. Ia ingin membangkitkan Islam dari keterpurukan. Artikel ini akan membahas pemikiran al-Jabiri untuk membangkitkan Islam. Kesimpulannya adalah: Pertama, orang Arab ketika Nabi Muhammad di utus, tidak mempunyai raja dan negara. Pada waktu itu sistem sosial politik di Makkah dan Yatsrib (Madinah) adalah sistem sosial kesukuan yang belum memenuhi persyaratan sebuah negara. Kedua, meskipun pada prakteknya Rasulullah saw. merupakan seorang pemimpin, komandan perang sekaligus pembimbing masyarakat muslim, beliau berulangkali menolak dengan keras untuk disebut sebagai raja atau pemimpin negara. Ketiga, pasca wafatnya Rasulullah, para sahabat beliau merasa bahwa ketiadaan Rasulullah berarti kekosongan institusional. Menurut Al-Jabiri klasifikasi nalar Arab adalah: Pertama, kelompok yang menolak apa saja yang bukan dari tradisi Islam. Kedua, kelompok sekuler-liberal yang menganggap kebangkitan tidak akan bisa dicapai kecuali mengikuti pola-pola Barat. Untuk tujuan ini Al-Jabiri menawarkan qiräab mu'ásirah terhadap tradisi yang ia sebut naqd al-'aql al-'arabi. Akal Arab dalam pandangan Al-Jabiri, terdiri dari bayāni, 'irfäni, burhāni. Bayāni adalah nalar yang berpijak kepada ilmu nahwu dan balaghab; 'irfani adalah nalar religios-sufistik dan burbāni adalah nalar yang mengandalkan rasio/akal.

Kata kunci: Agama, negara, pemikiran dan akal 


\section{Pendahuluan}

Dalam beberapa dekade terakhir ini trend pemikiran Islam baru telah mewarnai sejarah pemikiran Islam. Berbagai tokoh dan pemikir muslim bermunculan menyuarakan bagaimana seyogyanya kebangkitan Islam dimulai, apa sebab-sebab kemunduran Islam, bagaimana semestinya kemajuan dan pembaharuan itu dimulai. Mereka menyoal kembali warisan kebudayaan dan intelektual Islam. Salah satunya Muhammad Abied al-Jabiri. ${ }^{1}$

Al-Jabiri merupakan salah seorang pemikir Arab Islam terkemuka saat itu, yang telah mengemukakan berbagai gagasan segar dalam rangka proyek besarnya, yaitu proyek kebangkitan Islam (AnNabdah al-Islamiyyah) khususnya kebangkitan di lingkungan negaranegara Arab. ${ }^{2}$ Al-Jabiri juga seorang filosof Arab kontemporer yang dikenal sebagai pakar hermeneutik dan filsafat Islam. Lebih dari itu dia adalah jawara filsafat ilmu Arab yang tak tertandingi. Dia termasuk kelompok elit cendekiawan yang mengamati dengan seksama tradisi filsafat dalam legasi klasik hingga dapat menyarikan pemikiran, dan menyelami secara hidup legasi klasik itu dengan pemikirannya hingga sampai kepada filsafat. ${ }^{3}$ Dari sisi ini penulis mencoba memaparkan pemikiran Al-Jabiri sebagai sebuah proyek kebangkitan Islam, yaitu karya trilogi maqnum opusnya.

\section{Biografi M. Abied al-Jabiri}

Muhammad Abied al-Jabiri lahir pada tanggal 27 Desember 1935 di Figuig (Fuji), sebelah selatan Maroko. ${ }^{4}$ Pendidikan dari tingkat dasar sampai perguruan tinggi lebih banyak ditempuh di tanah kelahirannya di Maroko. Gelar doktornya diperoleh dari Universitas

1 M. Faishol, "Struktur Nalar Arab-Islam Menurut Al-Jabiri", Religio Jurnal Studi Agama-agama, Volume 01 No. 02, (September, 2011), 179

2 Muhammad Abied al-Jabiri, Agama Negara dan Penerapan Syariah. Yogyakarta : Fajar Pustaka Baru, 1996, 5.

${ }_{3}^{3}$ M. Aunul Abicd Shah, Islam Garda Depan, Mosaik Pemikiran Islam Timur Tengah. Bandung, Mizan, 2001, 299.

${ }^{4}$ Aksin Wijaya, Kritik Wacana Teologi Islam. Yogyakarta: IRCiSoD, 2019, 213. 
Muhammad V Rabath, Maroko, Tahun 1970.5 Dengan disertasi berjudul Fiker Ibn Kholdun Al-Ansabiyyah wa al-Daulab: Ma'alim Nazariyyah Khalduniyyah Fi al-Tarikh al-Islämi.

Disertasi ini baru dibukukan tahun 1971. Sejak 1976 menjadi staf pengajar pada fakultas sastra Universitas $\mathrm{V}$ Rabath dengan memegang bidang filsafat dan pemikiran Islam. Ia juga menjadi pengawas dan pengarah pendidikan bagi guru-guru ditingkat menengah atas. Di tangan para filsuf Perancis, khususnya Brunch Vigg dan Bachelard, Al-Jabiri memperoleh kematangan ilmu filsafat. Pengaruh kuat dari kedua filsuf ini tak dapat dipisahkan dari sosok Al-Jabiri. Ia menguasai tiga bahasa yakni Arab (bahasa Ibu) Perancis (baca tulis) dan Inggris (baca saja).

Sejak muda Al-Jabiri telah menjadi aktivis politik yang berideologi sosialis. Ia pernah aktif dalam partai Union National des Forces Popularies (UNFP) yang kemudian berubah nama menjadi Union Sosialiste des Forces Popularies (USFP). Pada tahun 1975 ia menjadi anggota biro politik USFP. ${ }^{6}$ Al-Jabiri termasuk pemikir yang produktif. Telah banyak buku yang ditulisnya antara lain: Dins Fi Al-Falsafah (1966), Fiker Ibn Khaldun Al-Asubiyyah Wali Allah Ad-Daulan (1976), Adwa ala Mushakìl al-Ta'tim (1973), Madkhal Ila Falsafah al-Ulum (1976), Min Ajl Ru'yah Taqaddumiyyah Li Ba'd Mushkilatina- al-Fikriyyah wa al-Tarbawiyyah (1977), Nahn wa al-Turäth (1980), Takwin Al-Aql Al-Arabi (1982), Bunyah Al-Aql Al-Arabi (1986) dan masih banyak karyanya yang lainnya.

\section{Pemikiran M. Abied al-Jabiri}

1. Agama dan Negara

Dalam beberapa tahun terakhir ini banyak perbincangan mengenai agama dan negara dalam hubungannya dengan implementasi hukum Islam. Rujukan dasar yang mendahului semua rujukan dalam pengalaman kesejarahan Islam Arab adalah

\footnotetext{
${ }^{5}$ M. Aunul Abied Shah, 301.

${ }^{6}$ M. Faishaol, 180.

${ }^{7}$ Mulyadhi Kartanegara, Pemikiran Islam Kontemporer. Yogyakarta: Jendela, 2003, 232; Budhy Munawar-Rachman, Argumen Islam Liberal untuk. Liberalisme Islam Progresif dan Perkembangan Diskursusnya. Jakarta: Grasindo, 2010, 80.
} 
praktek para sahabat periode kbulafä' al-räshidūn. Sebagaimana kita pahami dalam Islam teks-teks Al-Qur'an dan sunnah tidak mengatur hal-hal yang berkenaan dengan pemerintahan dan politik. Demikian juga Al-Qur'an dan As-Sunnah tidak terlibat dengan persoalan hubungan antara agama dan negara secara rinci dan jelas. Maka rujukan dasar, dalam hal hubungan antara negara dan agama serta implementasi hukum Islam adalah praktek para sahabat. Merekalah orang-orang yang menjalankan politik dan menopang bangunan negara serta menerapkan syariah berdasarkan pemahaman yang esensial terhadap ruh Islam.

Praktek tersebut jauh mendahului berbagai paham yang muncul dalam kerangka konflik dan perselisihan yang dikenal dalam sejarah Islam sejak konflik antara Ali dan Mu'awiyah. Benar bahwa dijaman khulafä' al-räshidūn juga terjadi pertentangan paham dan perbedaan sikap politik. Namun justru perbedaan dan pertentangan paham diantara para sahabat serta metode penyelesaiannya itulah yang membentuk suatu unsur dari apa yang disebut dengan "praktek sahabat". Sedangkan yang dimaksud "praktek sahabat" ialah seluruh praktek mereka dalam politik dan hukum baik berupa tindakan ataupun perkataan. Dengan demikian masalah ini berhubungan dengan pengalaman historis yang di bingkai, sebagaimana pengalaman-pengalaman lainnya, oleh data-data politik, sosial, ekonomi dan budaya yang membentuk bangunan sejarah di masyarakat di masa mereka. Oleh karena itu tulisan ini akan membahas faktor-faktor sosial historis yang membingkai tema "negara dan agama" di masa mereka. ${ }^{8}$

Fakta Pertama, adalah bahwa orang-orang Arab ketika Nabi Muhammad di utus, tidak mempunyai raja dan negara. Pada waktu itu sistem sosial politik di Mekkah dan Yatsrib (Madinah) adalah sistem sosial kesukuan yang belum memenuhi persyaratan

${ }^{8}$ Secara umum pemikiran Al-Jabiri lebih condong kepada paham sekulerisme. Tiar Anwar Bachtiar, Pertarungan Pemikiran Islam di Indonesia: Kritik-kritik Terhadap Islam Liberal dari HM. Rasjidi sampai INSIST. Jakarta: Pustaka al-Kautsar, 2017 , 370. 
sebuah negara, seperti berpijak pada wilayah teritorial tertentu dengan sejumlah penduduk yang tinggal di wilayah tersebut dan adanya kekuasaan pusat yang bertindak mengatur masalah bersama sesuai UU dan kebiasaan serta penggunaan kekerasan jika situasi menuntut. Masyarakat jazirah Arab sebelum Islam tidak mengenal kekuasaan seperti ini baik mereka yang di kota maupun di luar kota. Inilah makna "kebodohan (Jabiliyah) sebagaimana yang telah disifatkan Islam bagi kehidupan orang Arab sebelum diutusnya Nabi Muhammad.

Fakta Kedua, seiring dengan diutusnya Nabi Muhammad, kaum muslim mulai menjalankan agama baru yang bukan saja merupakan sikap individual di hadapan Tuhan namun juga merupakan perilaku sosial yang teratur. Perilaku sosial ini semakin berkembang seiring dengan dakwah Islam hingga mencapai puncaknya setelah Nabi hijrah ke Madinah. Pada masa itu, meski pada prakteknya Rasulullah saw. merupakan seorang pemimpin, komandan sekaligus pembimbing masyarakat muslim, beliau berulangkali menolak dengan keras untuk disebut sebagai raja atau pemimpin negara. Memang beliau terjun dalam berbagai pertempuran, memimpin ekspedisi militer, mengatur persoalanpersoalan masyarakat dan berusaha menjaga persatuannya, mengirim utusan dan mengangkat para pegawai, namun beliau melakukan semua itu bukan dalam kedudukannya sebagai pemimpin politik atau komandan militer, tapi dalam kedudukannya sebagai pembawa dakwah dan penyebar agama baru.

Fakta Ketiga, hal-hal yang ditentukan oleh perkembangan dakwah Islam berupa pengaturan persoalan-persoalan dunia, dunianya Rasulullah dan para sahabat, telah mencapai taraf yang mapan dan luas seiring dengan berakhirnya dakwah tersebut, sehingga membuat para sahabat Rasul yang sangat dekat dengan beliau merasa bahwa ketiadaan Rasulullah akan berarti kekosongan institusional. Walhasil dakwah Nabi telah berakhir

${ }^{9}$ Muḥammad Abied al-Jabiri, 1-8. 
bersamaan dengan terbentuknya satu negara atau sesuatu yang menyerupai negara. Jika agama adalah wahyu Allah yang tidak seorangpun berhak mewarisinya dari Rasulullah dan tidak pula untuk menggantikannya, maka pengaturan politik dan ekonomi masyarakat yang tumbuh bersamaan dengan pertumbuhan dan penyebaran dakwah, membuthkan adanya orang yang menjaga, mengatur serta memperhatikan perkembangannya setelah Rasulullah wafat.

Namun ada kesadaran di kalangan para sahabat sebelum wafatnya Rasulullah mengenai kebutuhan adanya "orang yang akan memegang kendali perintah" setelah beliau, sebagian dari bukti yang menunjukkan hal ini adalah apa yang disebutkan oleh para ahli sejarah terdahulu bahwa Abbas paman Nabi saw. mengangkat persoalan tersebut pada 'Ali bin Abi Țălib ketika Nabi sedang sakit menjelang ajalnya.

Fakta Keempat, Al-Qur'an yang berulang kali membicarakan perihal "ummat", umat Islam dan kaum muslim (kalian adalah sebaik-baik umat yang diutus kepada manusia) (QS. A 'Imrān: 110) justru menghindar dari pembicaraan mengenai sistem politik, sosial dan ekonomi yang sebenarnya telah menyatukan umat tersebut dengan negara. Memang benar bahwa Al-Qur'an telah menetapkan hukum sanksi, menghalalkan dan mengharamkan, menetapkan berbagai kewajiban dan pelaksanaan menuntut adanya seorang pemegang "perintah". Al-Qur'an mengajak dengan ungkapan yang eksplisit untuk mematuhi para pemimpin (Hai orang-orang yang beriman, patubilah Allah dan patubilah Rasul serta para pemimpin kalian (QS. An-Nisa : 59), sebagaimana Al-Qur'an juga mencela kesewenang-wenangan dan keangkuhan serta memuji musyawarah, berbuat baik dan berlaku adil. Akan tetapi Al-Qur'an tidak menyebutkan tentang orang yang akan menggantikan Rasul dalam mengelola persoalanpersoalan umat. ${ }^{10}$

${ }^{10}$ Ibid., 8-12 
Fakta Kelima, perdebatan yang terjadi di Saqifah Bani Sa'idah yang berakhir dengan pembai'atan Abū Bakar sebagai pengganti Rasulullah, merupakan perdebatan politik murni dan diselesaikan berdasarkan pertimbangan kekuatan sosial politik (kesukuan) saat itu. Karena para sahabat itu menangani persoalan khilafah dengan penanganan politik murni. Mereka menganggap persoalan itu merupakan persoalan ijtihadiyah dan mereka bergulat dengan persoalan tersebut atas dasar sifatnya yang ijtihadiyah itu.

Adapun dalam persoalan "Aqidah", kaum Muhäjirin dan Anșār saat itu relatif berada pada tingkatan yang sama sehingga pernyataan pamungkas yang dijadikan argumen oleh Abū Bakar adalah: "orang-orang Arab tak akan tunduk kecuali dipimpin oleh kaum Quraisy". Pandangan ini adalah pandangan obyektif yang mengakui persoalan riil sehingga kaum Anșār bisa menerima pendapat tersebut pada saat dikalangan mereka sendiri mulai bangkit rasa "kesukuan" sempit (persaingan antara suku Aus dan Khazraj), begitu pula mereka menyadari bahwa pandangan kaum Muhajirīin adalah tepat dalam mempertimbangkan kemaslahatan bersama.

Demikian pula tak perlu dipersoalkan bagaimana cara 'Umar, Ushmān dan 'Ali di bai' at serta argumen-argumen mereka dalam perdebatan, musyawarah dan pertimbangan kekuatan. Sesungguhnya politiklah yang menentukannya, bukan agama, yang menjadi materi perdebatan dan perbedaan, serta dalam kerangka politik itulah dibuat kesepakatan dan keputusan. Dari fakta historis inilah nampak jelas bahwa persoalan "hubungan antara agama dan negara" tidak pernah terlontar di zaman Nabi dan tidak pula dimasa kbulafä' al-räshidūn. Pada zaman Nabi saw. seluruh upaya dicurahkan untuk menyebarkan dan membela agama.

Kaum muslim dimasa sahabat tidak memandang Islam sebagai "dawlah" (negara) dalam pengertian tersebut, yakni sesuatu yang berpindah-pindah dari tangan satu ke tangan yang lain, yang menghilang setelah wujud dan seterusnya. Sesungguhnya kaum muslim saat itu memandang Islam sebagai agama pamungkas 
yang mengakhiri semua agama. Dengan demikian, hubungan antara negara dan agama bukan termasuk salah satu tema pemikiran di zaman Nabi dan dimasa al-khulafä, al-räshidūn. Yang menjadi fokus pemikiran dan perhatian sejak Rasulullah sakit hingga menjelang ajalnya ialah apa yang diistilahkan oleh para ahli kalam sebagai "al-imämah" atau "al-kbïlafah". Masalah ini adalah masalah politik murni sekaligus menjadi masalah pertentangan besar paling mula-mula dalam sejarah Islam. ${ }^{11}$

2. Membongkar Bangunan Tradiri Islam

Menurut Al-Jabiri, tradisi (al-turäth) adalah sesuatu yang hadir dan menyertai kekinian kita, yang berasal dari masa lalu, apakah itu masa kita atau masa lalu orang lain, ataukah masa lalu tersebut adalah masa lalu yang jauh maupun yang dekat. Dua hal yang penting untuk diperhatikan dari definisi ini adalah: Pertama, bahwa tradisi adalah sesuatu yang menyertai kekinian kita, yang tetap hadir dalam kesadaran atau ketidaksadaran kita. Kedua, tradisi yang mencakup tradisi kemanusiaan yang lebih luas seperti pemikiran filsafat dan sains. Kedua ini menurut Al-Jabiri sebagai at-turāth al-insāni.

Ada beberapa sikap yang berkembang dalam masyarakat Islam terhadap tradisi itu. Pertama, mereka yang menolak apa saja yang bukan dari tradisi Islam karena apa yang ada dalam tradisi tersebut sudah memadai. Ini terdiri dari dua kelompok yang cukup berbeda, yang satu adalah mereka yang hanya hidup dan berfikir dalam kerangka tradisi itu, yakni para ulama konservatif, dan yang kedua adalah mereka yang justru tidak memiliki pengetahuan yang memadai terhadap tradisi karena mereka sebenarnya dididik dalam tradisi lain, yakni tradisi Barat. Kedua, mereka yang menganggap bahwa tradisi sama sekali tidak memadai dalam kehidupan modern saat ini, karena itu ia harus dibuang jauh-jauh. Kelompok ini adalah mereka yang berfikiran

${ }^{11}$ Ibid, 13-16 
sekuler dan liberal ala Barat sehingga menganggap kebangkitan tidak akan bisa dicapai kecuali mengikuti pola-pola Barat.

Untuk tujuan ini Al-Jabiri kemudian menawarkan apa yang ia sebut sebagai telaah kontemporer (qiräab mu'asisab) terhadap tradisi, telaah kontemporer ini kemudian diwujudkan dalam sebuah proyek yang ia sebut "kritik akal Arab (Naqd al-Aql Al-Arabi). ${ }^{12}$

\section{Akal Arab dan Titik Awalnya}

Akal Arab dalam trilogi Al-Jabiri, yaitu kumpulan prinsip dan kaidah yang diberikan oleh peradapan Arab kepada para pengikutnya sebagai landasan memperoleh pengetahuan, atau sebagai aturan epistemologis, yakni sebagai kumpulan konsep dan prosedur yang menjadi struktur bawah sadar dari pengetahuan dalam fase sejarah tertentu. Al-Jabiri melihat bahwa kumpulan konsep dan prosedur pemikiran yang mengatur dengan ketat cara pandang orang Arab dan pola interaksinya dengan sesuatu itu memang ada. Berarti, orang Arab adalah individu anak manusia yang akalnya terbuka, tumbuh dan berkembang dalam peradapan Arab, hingga (peradapan Arab itu) memformat referensi pemikirannya yang utama. Sebagaimana diketahui, ada tiga titik pijak yang biasa digunakan sebagai permulaan penulisan sejarah Arab, yaitu masa jahiliyah, masa Islam dan masa kebangkitan.

Al-Jabiri sendiri berketepatan untuk mengambil jalan berbeda dengan memulainya dari era kodofikasi ('asr al-tadwin) pertengahan abad II. Tanpa menafikkan masa jahiliyah dan produk-produknya. Begitu juga pengaruh masa Islam awal dalam peradaban Arab. Al-Jabiri berpendapat bahwa struktur akal Arab telah dibakukan dan di sistematisasikan pada era kodifikasi tersebut. Sehingga konsekuensinya, dunia berfikir yang dominan pada masa itu mempunyai kontribusi terbesar dalam menentukan orientasi pemikiran yang berkembang kemudian disatu pihak dan di pihak lain mempengaruhi persepsi kita terhadap khazanah pemikiran yang berkembang pada masa sebelumnya.

12 Ibid, vii - $\mathrm{x}$ 
Dengan demikian, Al-Jabiri telah keluar dari metode penulisan sejarah Arab yang lazim dan menawarkan metode baru bagi sejarahwan Arab. ${ }^{13}$

\section{Struktur Akal Arab}

1. Nalar Bayāin

Kata bayān berasal dari akar kata bayana. Dalam kamus bahasa Arab, kata ini memiliki arti kata pisah atau terpisah (al-fash /al-infihal), jelas atau menampakkan (al-zahar/al-iz̧här). Sesuatu dikatakan jelas apabila ia berbeda dari yang lain atau memiliki keistimewaan dibanding dengan yang lain. Oleh karena itu, pengertian yang kedua (al-z̧abar/al-iz̧här) lahir dari pengertian yang pertama (al-fahsl / al-infishal). Menurut Al-Jabiri pengertian yang pertama secara mendasar terkait dengan wujud ontologis, sementara pengertian yang kedua terkait dengan wujud epistemologis. Dalam peradapan Arab-Islam, diskusi mengenai kajian-kajian bayāi dikelompokkan menjadi dua. Pertama, terkait dengan aturan dalam menafsirkan wacana, dan kedua, terkait dengan syarat memproduksi wacana. Syarat memproduksi wacana dalam tradisi bayan i baru dimulai seiring dengan munculnya faksifaksi politik dan aliran-aliran teologi setelah peristiwa majlis tahkim dimana wacana dan debat teologis menjadi instrumen untuk menebarkan pengaruh dan propaganda kepada "yang lain" dan bahkan menaklukkan musuh.

Menurut Al-Jabiri, nalar bayāni terdapat dalam kajian ilmu kebahasaan. Nahwu, fikih, teologi dan ilmu balaghah. Nalar bayāni bekerja dengan menggunakan mekanisme yang sama, berangkat dari dikotomi antara laf / / al-ma'na, al-asl / al-far' dan al-ardh. Dalam kajian ilmu nahwu, persoalan al-laf: dan al-ma'na dapat dilihat secara jelas dalam mendiskusikan tentang asal-usul bahasa: apakah wahyu Tuhan atau konvensi masyarakat. Dalam hal ini terdapat dua aliran dalam mensikapi teori tentang asal-usul bahasa. Pertama, aliran rasional yaitu Mu'tazilah yang berpendapat bahwa bahasa adalah konvensi masyarakat. Kedua, non rasional yaitu

${ }^{13}$ M. Aunul Abied, 306-311 
Ahlusunnah, yang menyatakan bahwa bahasa adalah wahyu Tuhan. Jadi yang menjadi perdebatan tidak lain adalah sosok pencipta bahasa, antara masyarakat atau Tuhan, ini yang menjadi poros diskusi ahli nahwu. ${ }^{14}$

Dalam wilayah ilmu kalam persoalan hubungan antara alașl dan al-far', termanifestasi dalam metode penalaran yang dikenal dengan al-istidlal bi al-shabid ala al-ghayb. Kalangan mutakallimun berbeda pendapat mengenai apakah melalui akal atau wahyu seseorang dapat mengetahui baik dan buruk. Muktazilah menyatakan bahwa seseorang dengan akalnya akan dapat mengetahui baik dan buruk, sementara kalangan Sunni, meyakini bahwa hanya dengan wahyu seseorang dapat mengetahui baik dan buruk.

Mu'tazilah mengakui dekat al-shahid sebagai sumber untuk mengetahui kebaikan karena yang shabid tidak selalu memberikan pemahaman, sebaliknya al-shabid (alam) lawan dari al-ghayb (Allah). Tetapi yang shabid bisa berarti semisal dengan-Nya, karena ia merupakan asal bagi sesuatu yang ghaib. Oleh karena itu akal (alshabid) tidak lain adalah jalan untuk mengetahui yang ghaib (Allah). Sementara kalangan-kalangan sunni memahami al-shabid sebagai lawan al-ghayb yang shahid bersifat terbatas yang berarti lawan dari Allah (al-Ghayb) yang tidak terbatas. Perbedaan antara Muktazilah dan Sunni hanya terbatas pada cara memaknai terhadap al-shabid dan al-ghayb.

2. Nalar 'Irfäi

Trfän merupakan bentuk masdar dari kata 'arafa yang berarti al-ilm, dan sinonim dengan kata al-ma'rifah. Kata itu dikenal dalam kalangan sufi muslim (al-mutasawnifah al-islamiyah) untuk menunjukkan jenis pengetahuan yang paling luhur yang hadir di dalam kalbu melalui kashf atau ilham, ${ }^{15}$ yaitu tersingkapnya rahasia-rahasia realitas oleh Tuhan yang diperoleh berdasarkan dengan olah rohani, dimana dengan kesucian hati diharapkan

${ }^{14}$ M. Faishol, 181-182

${ }^{15}$ Ibid., 183-184 
Tuhan akan melimpahkan pengetahuan langsung kepadanya. Dari situ kemudian dikonsepsikan atau masuk ke dalam pikiran sebelum dikemukakan kepada orang lain. Sebagaimana disampaikan Suhrawardi, secara metodologis pengetahuan ruhani setidaknya diperoleh melalui tiga tahapan yaitu persiapan, penerimaan dan pengungkapan, baik dengan lisan atau tulisan.

Tahapan pertama adalah persiapan. Untuk bisa menerima limpahan pengetahuan (kashf), seseorang yang disebut sälik. (penempuh jalan spiritual) harus menyelesaikan jenjang-jenjang kehidupan spiritual. Setidaknya ada tujuh tahapan yang harus dijalani:

\section{a. Tobat}

Tobat adalah meninggalkan segala peruatan yang kurang baik disertai penyesalan yang mendalam untuk kemudian menggantinya dengan perbuatan-perbuatan baru yang terpuji. Menurut Al-Qusyairi, tobat adalah landasan dan tahapan pertama bagi perjalanan spiritual berikutnya jika seseorang tidak berhasil pada tahapan ini, ia akan sulit untuk naik pada jenjang berikutnya/

b. Wara'

Wara' adalah menjauhkan diri dari segala sesuatu yang tidak jelas statusnya (subhat). Wara' juga dibagi dua wara lahir, yaitu tidak melakukan sesuatu kecuali untuk beribadah kepada Tuhan. Sedangkan wara' batin, yaitu tidak memasukkan sesuatu apapun dalam hati kecuali Tuhan.

c. Zubud

Zuhud adalah tidak tamak dan tidak mengutamakan kehidupan dunia. Zuhud juga diartikan bahwa hati tidak tersibukkan oleh sesuatu apapun kecuali Tuhan (meski disana ada banyak kekayaan) semuanya tidak berarti hatinya dan tidak memberi pengaruh dalam hubungannya dengan Tuhan.

d. Faqī

Faqiir adalah mengosongkan seluruh pikiran dan harapan dari kehidupan masa kini dan masa yang akan datang serta 
tidak mungkin dari sesuatu apapun kecuali Tuhan. Tingkat faqï merupakan realisasi dari upaya pensucian hati secara keseluruhan dari segala hal selain Tuhan.

e. Sabar

Sabar adalah menerima segala bencana dengan laku sopan dan rela. Ini tahapan lebih lanjut setelah seseorang mencapai tingkat faqir.

f. Tawakeal

Tawakkal adalah percaya atas segala apa yang ditentukan Tuhan. Jika mengalami kesulitan ia akan menyadari bahwa itu berarti takdir-Nya dan jika berhasil berarti atas kemudahanNya.

\section{g. Rida}

Rida adalah hilangnya rasa ketidak-senangan dalam hati sehingga yang tersisa hanya bahagia dan sukacita. Ini adalah puncak dari tawakeal.

Tahap kedua adalah penerimaan. Jika telah mencapai tingkat tertentu dalam sufisme, seseorang akan mendapatkan limpahan pengetahuan langsung dari Tuhan secara iluminatif. Dalam kajian filsafat Mehdi Yazdi, pada tahap ini, seseorang akan mendapatkan realitas kesadaran diri yang demikian mutlak (kashf), sehingga dengan kesadaran itu ia mampu melihat realitas dirinya sendiri (mushăhadah) sebagai objek yang diketahui. Namun realitas kesadaran dan realitas yang disadari tersebut bukan objek eksternal, keduanya bukan sesuatu yang berbeda tetapi merupakan eksistensi yang sama, sehingga objek yang diketahui tidak lain adalah kesadaran yang mengetahui itu sendiri, begitu pula sebaliknya (ittihad).

Tahap ketiga adalah pengungkapan. Fase ini merupakan tahap terakhir dari proses pencapaian pengetahuan irfäi, dimana pengalaman mistik di interpretasikan dan diungkapkan kepada orang lain. Lewat ucapan atau tulisan. Namun karena pengetahuan irfani bukan masuk tatanan konsepsi dan representasi tetapi terkait dengan kesatuan simpleks kehadiran 
Tuhan dalam diri dan kehadiran diri dalam Tuhan. Dengan demikian tidak bisa dikomunikasikan dan tidak semua pengalaman ini diungkapkan tentang lahir dan batin. ${ }^{16}$ Isu sentral dari irfäni adalah zăhir dan bătin, bukan sebagai konsep yang berlawanan tetapi sebagai pasangan. Menurut Muhasibi (w.857 M), Al-Ghazali (w. 1111 M), Ibn Arabi (w.1240 M), juga para sufi yang lain, teks keagamaan (Al-Qur'an dan Hadis) tidak hanya mengandung apa yang tersurat (zăbir) tetapi juga apa yang tersirat (bätin). Zähir teks adalah bacaannya (tilawab) sedangkan aspek batinnya adalah takwil-nya. Jika dianalogikan dengan bayani, konsep zăbir-bătin ini tidak berbeda dengan lafal-makna. Bedanya, dalam epistemologi bayāni, seseorang berangkat dari lafal menuju makna. Sedangkan dalam irfani, seseorang justru berangkat dari makna menuju lafal, dari batin menuju zăhiri

\section{Nalar Burhāni}

Berbeda dengan epistemologi bayāni dan irfäni, yang masih berkaitan dengan wacana, sedang burhäni sama sekali tidak mendasarkan pada wacana (teks), juga tidak pada pengalaman. Burbāni menyandarkan diri pada kekuatan rasio, akal, yang dilakukan lewat dalil-dalil logika. Bahkan dalil-dalil agama hanya bisa diterima sepanjang ia sesuai dengan logika rasional. Perbandingan ketiga epistemologi ini seperti dijelaskan Al-Jabiri, bayani menghasilkan pengetahuan lewat analogi realitas non-fisik atas realitas fisik atau furu' kepada yang asal, 'irfäni menghasilkan pengetahuan lewat proses penyatuan ruhani pada Tuhan dengan penyatuan universal (kulliyat). Burbäni menghasilkan pengetahuan melalui prinsip-prinsip logika atas pengetahuan sebelumnya yang telah diyakini kebenarannya.

Dengan demikian, sumber pengetahuan burbāni adalah rasio, bukan teks atau intuisi. Rasio inilah yang digunakan dengan dalil-dalil logika, sehingga memberikan penilaian dan keputusan

${ }^{16}$ Mulyadhi Kartanegara, 241-244 
terhadap informasi-informasi yang lewat indra yang dikenal dengan istilah tasawwur dan tasdiq. Tasawnur adalah proses pembentukan konsep berdasarkan data-data dari indra, sedang tasdiq adalah proses pembuktian terhadap kebenaran konsep tersebut. Selanjutnya untuk mendapatkan sebuah pengetahuan, epistemologi burhāni menggunakan aturan silogisme. Secara istilah, silogisme adalah suatu bentuk argumen dimana dua proposisi yang disebut premis, dirujukkan bersama sedemikian rupa, sehingga sebuah keputusan (konklusi) pasti menyertai. Namun, karena pengetahuan burhāni tidak murni bersumber pada rasio, tetapi didasarkan juga atas rasio objek-objek eksternal, maka ia harus melalui tahapan-tahapan sebelum dilakukan silogisme. Pertama, tahap pengertian (ma'qülat) kedua, tahap pernyataan ('ibärat), dan ketiga, tahap penalaran (tạ̣lilat).

Tahap pengertian adalah proses abstraksi atas objek-objek eksternal yang masuk ke dalam pikiran. Tahap pernyataan adalah proses pembentukan kalimat atau proposisi atas pengertianpengertian yang ada. Proposisi ini harus memuat unsur subjek (maudu) dan predikat (mạmūi) serta adanya relasi di antara keduanya, dan dari sana hanya lahir satu pengertian serta kebenaran, yakni adanya kesesuaian dengan objek. Tahap penalaran adalah proses pengambilan kesimpulan berdasarkan hubungan diantara premis-premis yang ada, dan disinilah terjadi silogisme. Menurut Al-Jabiri dengan mengikuti Aristoteles, penarikan kesimpulan dengan silogisme ini harus memenuhi beberapa syarat.

a. Mengetahui latar belakang dari penyusunan premis

b. Adanya konsisten logis antara alasan dan kesimpulan

c. Kesimpulan yang diambil harus bersifat pasti dan benar, sehingga tidak mungkin menimbulkan kebenaran atau kepastian lain. $^{17}$

${ }^{17}$ Ibid., 250-251 
Al-Farabi sebagai tokoh filsafat dalam Islam mensyaratkan bahwa premis-premis burhāni harus berupa premispremis yang benar, primer dan diperlukan. Premis yang benar adalah premis yang memberi keyakinan meyakinkan. Al-Farabi membagi materi premis-premis silogisme ke dalam empat bentuk. Pertama, pengetahuan primer. Kedua, Pengetahuan indrawi (mậsusat). Ketiga, opini-opini yang umumnya diterima (mashbürat). Keempat, opini-opini yang diterima (maqbülat).

Keempat macam premis ini tidak sama tingkat kepercayaannya, ada yang mencapai tingkat meyakinkan, mendekati keyakinan dan percaya begitu saja. Sehingga memunculkan hierarki tingkat hasil silogisme. Suatu premis bisa dianggap meyakinkan bila memenuhi tiga syarat. Pertama, kepercayaan bahwa sesuatu (premis) itu berada atau tidak dalam kondisi spesifik. Kedua, kepercayaan bahwa sesuatu itu tidak mungkin merupakan sesuatu yang lain selain darinya. Ketiga, kepercayaan bahwa kepercayaan kedua tidak mungkin sebaliknya. Premis dianggap mendekati keyakinan jika hanya mengacu kepada dua kriteria pertama. Sedangkan yang dipercaya belaka mempersyaratkan kriteria pertama diantara tiga kriteria yang diberikan.

\section{KESIMPULAN}

Proyek pemikiran Abied al-Jabiri telah memberikan warna tersendiri dalam pembaharuan Islam. Kritik epistemologi yang ditawarkan membuka pada dunia Islam akan rusaknya bangunan nalar epistemik yang selama ini beroperasi di tengah peradapan Islam. Kritik yang ditawarkan Al-Jabiri yaitu trilogi magnum opus-nya. Dalam memulai kritiknya Al-Jabiri membahas mengenai tradisi (al-turäth), menurutnya tradisi merupakan sesuatu yang menyertai kekinian kita, yang tetap hadir dalam kesadaran atau ketidak sadaran kita, yang mencakup tradisi kemanusiaan yang lebih luas seperti pemikiran filsafat dan sains. 
Akal Arab, adalah kumpulan prinsip dan kaidah yang diberikan oleh peradapan Arab kepada para pengikutnya sebagai landasan memperoleh pengetahuan, atau sebagai aturan epistemologi. Al-Jabiri melihat bahwa kumpulan konsep dan prosedur pemikiran yang mengatur dengan ketat pola pandang orang Arab dan pola interaksinya dengan sesuatu itu memang ada. Berarti, orang Arab adalah individu anak manusia yang akalnya terbuka, tumbuh dan berkembang dalam peradapan Arab.

Lebih lanjut lagi yaitu struktur nalar Arab yang merupakan pembahasan, yakni nalar bayāni didasarkan pada wacana (teks), metode irfani di dasarkan pada intuisi. Sedangkan metode burbäni pada rasio. Dalam sejarahnya masing-masing juga pernah mengantarkan penganutnya pada pencapaian puncak. Bayani, menghasilkan para ahli figh besar, 'irfani memunculkan tokoh sufisme terkenal dan burbäni menampilkan para filosof yang disegani. 


\section{DAFTAR PUSTAKA}

Bachtiar, Tiar Anwar. Pertarungan Pemikiran Islam di Indonesia: Kritik-kritike Terbadap Islam Liberal dari HM. Rasjidi sampai INSIST. Jakarta: Pustaka al-Kautsar, 2017.

Faishol M. "Struktur Nalar Arab-Islam Menurut Abied al-Jabiri”, Religio Jurnal Studi Agama-agama. Vol. 01 No. 02, September, 2011.

Jabiri, (al) Muhammad Abid. Agama Negara dan Penerapan Syariah. Yogyakarta: Fajar Pustaka Baru. 1996.

Kartanegara, Mulyadhi. Pemikiran Islam Kontemporer. Yogyakarta: Jendela, 2003.

Rahman, Budhy Munawar. Argumen Islam Liberal untuk. Liberalisme Islam Progresif dan Perkembangan Diskursusnya. Jakarta: Grasindo, 2010.

Shah, M. Aunul Abied. Islam Garda Depan, Musaik Pemikiran Islam Timur Tengah. Bandung : Mizan, 2001.

Wijaya, Aksin. Kritik Wacana Teologi Islam. Yogyakarta: IRCiSoD, 2019. 